\title{
Collapse of Device
}

National Cancer Institute

\section{Source}

National Cancer Institute. Collapse of Device. NCI Thesaurus. Code C63272.

Problem associated with the buckling or crushing of material from external forces. 